\title{
北海道における温室効果ガス排出削減目標に対する 長期的な最適導入技術解析
}

\author{
藤原 貴弘 ${ }^{* 1}$, 田部 豊*2, 近久 武美*3

\begin{abstract}
Analysis of long-term optimal introduction of technologies for the reduction of greenhouse gas in Hokkaido
\end{abstract}

\author{
Takahiro FUJIWARA ${ }^{* 1}$, Yutaka TABE*2 and Takemi CHIKAHISA ${ }^{* 3}$ \\ ${ }^{*} 1,{ }^{*},{ }^{*}$ Hokkaido University \\ Kita 13, Nishi 8, Kita-ku, Sapporo 060-8628, Japan
}

Received: 5 October 2017; Revised: 19 January 2018; Accepted: 9 February 2018

\begin{abstract}
This study analyzes cost-minimum combination of long-term introduction of technologies for the given targets of integrated $\mathrm{CO}_{2}$ emissions from 2010 to 2050 . The area covers all sections of power generation, industry, home \& office, transportation, and others. The analysis was made with MARKAL MODEL, a linear programing model, modified to be available for renewable energies with daily and seasonal fluctuation. Input data are given from variety of official statistics. The results show the relationship between the $\mathrm{CO}_{2}$ reduction amount and the increased cost: for example, the maximum limit of the integrated $\mathrm{CO}_{2}$ reduction for the period is $38 \%$, when the integrated total cost increases $18 \%$ compared to the case with no $\mathrm{CO}_{2}$ limitation. When the $\mathrm{CO}_{2}$ limitation becomes $20 \%$, increased cost changes to $3 \%$. The number itself changes in some extent depending on the input data, but it gives ideas of the trends in the total relationship. As the $\mathrm{CO}_{2}$ reduction rate increases, coal power plants are gradually replaced by combined cycle of natural gas, and then by wind and solar. The influence of the $\mathrm{CO}_{2}$ limitation is large in the home \& office sector and the industry sector due to the increased cogeneration system and electricity from lower $\mathrm{CO}_{2}$ power plants. However, the $\mathrm{CO}_{2}$ emission from steel and paper industries and transportation sector remains almost same. This result in transportation sector is due to the reason that the hybrid cars take share similarly regardless of the $\mathrm{CO}_{2}$ limitation, and that electric and fuel cell cars take little share in this analysis conditions.
\end{abstract}

Keywords : $\mathrm{CO}_{2}$ reduction, Cost, MARKAL model, Linear programming, Energy structure, Hokkaido

\section{1. 緒言}

将来の地球温暖化抑制を目的として，2015 年 12 月に第 21 回気候変動枠組条約締約国会議（COP21）において パリ協定が締結され，これを受けて日本は 2030 年までに 2013 年比 $26 \%$ 二酸化炭素排出削減を目標に掲げてい るほか，さらに 2050 年までに 80\%程度の削減努力が求められている. 目標を達成するためには，コストの増加 を最小に抑えながら再生可能エネルギ一の大量導入を始めとした長期的な視点に基づく大幅な設備構成の変更が 必要である．著者らはこれまでに効果的な $\mathrm{CO}_{2}$ 排出削減を行うための選択肢を示すことを目的として，再生可能 エネルギー導入ポテンシャルが高い北海道を対象とした北海道版 MARKAL モデルの開発を行ってきた（柳他， 2015). ただし，従来型 MARKAL モデルではその特性上，日変動や季節変動を伴う再生可能エネルギーに対する 解析が不十分であり，設備稼働率による平均的な出力を与えた場合には再生可能エネルギーが過大評価される特 性があった．そこで本研究では，実際の 1 時間単位の電力需給バランスデータを用いたサブモデルによる解析を

No.17-00449 [DOI:10.1299/transjsme.17-00449], J-STAGE Advance Publication date : 20 February, 2018

本論文は，第22回動力・エネルギ一技術シンポジウム 講演論文集(2017), No.E213の掲載内容に基づいた論文である.

*1 学生員, 北海道大学大学院工学院（干060-8628 北海道札幌市北区北 13 西 8)

*2 正員, 北海道大学大学院工学研究院

*3 正員, フェロー, 北海道大学大学院工学研究院

E-mail of corresponding author: t.fujiwara@eng.hokudai.ac.jp 
別途行い，その結果を北海道版 MARKAL モデルへ反映させることとした.

解析は 2010 年から 2050 年に亘る積算 $\mathrm{CO}_{2}$ 量を制約条件とし, その $\mathrm{CO}_{2}$ 量を達成しながらコスト最小となる設 備や燃料の組合せを求めた. 解析の結果, 本解析条件における $\mathrm{CO}_{2}$ 削減量の限界やその際のコス卜増加量, なら びにエネルギー消費部門ごとの変化等を示すことができた．また，より一層 $\mathrm{CO}_{2}$ を削減する場合に取り組む必要 のある部門やそのための技術オプションについて論ずることができた.

なお，将来のエネルギ一分析に関する資料は多数あるが，学術論文として公表されたものは少なく，最近のも のでは（秋元，佐野，2017），(Komiyama and Fujii, 2017)，(Sakamoto et al., 2016）があるほか, エネルギーシス テム・経済・環境コンファレンスでいくつか発表されている.ただし, 北海道を対象としたものはほとんどない. なお，この種の研究は様々な角度から分析されるべきものであり，その点，独創性等を重視する他の技術論文と は多少異なった特徴があるといえる。

\section{2. 解析手法}

\section{$2 \cdot 1$ MARKAL モデルの概要}

解析には, ブルックヘブン国立研究所で開発され(Richard, 2004), 日本原子力研究所で日本版に修正されたエネ ルギーシステム解析モデル MARKAL(佐藤, 2005)をべースとして用い, 必要なデータを北海道に合わせて修正し た. MARKAL モデルは特定の地域に供給される全ての 1 次エネルギーや利用可能な技術のコストおよび性能の ほか, 部門ごとの最終需要を入力し, 需要を満たしながら特定の期間に亘る総コストが最小となるエネルギーシ ステム構成を線形計画モデルにより求める解析プログラムである. この際, 例えば解析期間中の総排出 $\mathrm{CO}_{2}$ 量を 制約条件として与えると, 制約条件を満たした組合せの中でコスト最小の解が導かれる.

MARKAL モデルの基本的な枠組みは, エネルギーキャリア（一次エネルギー，最終需要エネルギー，システ ムにおいて中間的に生成されるエネルギー), エネルギー技術（供給技術，需要技術），エネルギーサービスから 構成されている. エネルギーキャリアのうち一次エネルギーは，エネルギーシステムの解析対象地域と外部地域 に分けて取り扱われており，輸入資源，国内（道内）資源，再生可能資源，輸出資源のカテゴリに大別される. そして各々のカテゴリは, 石炭, 原油, 風力エネルギーなどの細かい資源種に分別・構成されている. 一方, エ ネルギー技術のうち，供給技術は電力と熱を供給する変換技術およびそれ以外のエネルギーキャリアを精製，変 換, 貯蔵, 輸送するプロセス技術に分類される. また, 最終需要技術は上流のエネルギー供給技術から出力され るエネルギーを最終的な要求需要に対して供給するものである. さらにこの最終利用技術は, 大別して産業, 民 生 (業務・家庭)，輸送に部門分けされている.

これらの構成要素には, 多くの入力情報が必要であり, 本研究では前述の通り日本版 MARKAL モデルをベー スに, 必要に応じて解析対象地域内の各エネルギー供給会社, 官公庁が公表している各種資料等を参考に, 将来

Table 1 Primary energy price

\begin{tabular}{|l|ccccccccc|}
\hline & \multicolumn{7}{|c|}{ Prices of Primary Energies [ $100,000,000 ¥ /$ PJ ] } \\
& 2010 & 2015 & 2020 & 2025 & 2030 & 2035 & 2040 & 2045 & 2050 \\
\hline Import Coal & 2.41 & 3.05 & 3.70 & 3.91 & 4.11 & 4.23 & 4.34 & 4.46 & 4.58 \\
Import Light Oil & 8.40 & 10.6 & 12.9 & 13.6 & 14.3 & 14.7 & 15.1 & 15.5 & 15.9 \\
Import Heavy Oil & 6.47 & 8.19 & 9.91 & 10.5 & 11.0 & 11.3 & 11.6 & 12.0 & 12.3 \\
Import Gasoline & 8.61 & 10.9 & 13.2 & 13.9 & 14.7 & 15.1 & 15.5 & 15.9 & 16.3 \\
Import LPG & 7.68 & 9.72 & 11.8 & 12.4 & 13.1 & 13.5 & 13.8 & 14.2 & 14.6 \\
Import Kerosene & 9.82 & 12.4 & 15.0 & 15.9 & 16.7 & 17.2 & 17.7 & 18.1 & 18.6 \\
Import LNG & 6.14 & 7.27 & 8.39 & 8.86 & 9.33 & 9.57 & 9.83 & 10.1 & 10.4 \\
Import Uranium & 0.05 & 0.05 & 0.05 & 0.06 & 0.06 & 0.06 & 0.06 & 0.06 & 0.06 \\
\hline Domestic Coal & 2.41 & 3.05 & 3.70 & 3.91 & 4.11 & 4.23 & 4.34 & 4.46 & 4.58 \\
Domestic LNG & 6.14 & 7.27 & 8.39 & 8.86 & 9.33 & 9.57 & 9.83 & 10.1 & 10.4 \\
\hline
\end{tabular}


Table 2 Electric power generation equipment

(*1 O\&M : Operation and Maintenance, *2 At the start of analysis)

\begin{tabular}{|c|c|c|c|c|c|}
\hline & $\begin{array}{c}\text { Installation Cost } \\
{[10,000 ¥ / \mathrm{kW}]}\end{array}$ & $\begin{array}{c}\text { O\&M }{ }^{* 1} \text { Cost } \\
{[10,000 ¥ / \mathrm{kW} / \text { year }]}\end{array}$ & $\begin{array}{c}\text { Residual Capacity }^{* 2} \\
{[\mathrm{GW}]}\end{array}$ & $\begin{array}{c}\text { Efficiency } \\
{[\%]}\end{array}$ & $\begin{array}{c}\text { Lifespan } \\
\text { [Yaer] }\end{array}$ \\
\hline Coal & 23.0 & 1.07 & 2.25 & 39.7 & 40 \\
\hline Hevy Oil & 19.0 & 0.84 & 1.90 & 36.7 & 40 \\
\hline Nuclear & 35.0 & 1.46 & 1.16 & 40.9 & 60 \\
\hline Hydro & 84.9 & 1.59 & 1.23 & - & 60 \\
\hline Geothermal & 79.9 & 1.69 & 0.25 & - & 30 \\
\hline Wind & 27.5 & 0.64 & 0.25 & - & 20 \\
\hline Solar & 45.0 & 0.32 & 0.00 & - & 30 \\
\hline LNGCC & 12.0 & 1.06 & 0.00 & 52.0 & 40 \\
\hline
\end{tabular}

の見通しを考慮したエネルギー需要や燃料価格，およびエネルギー技術ごとにコストや効率，導入可能規模など の特性データを入力した. これらの入力情報を基に, 与えられた制約条件を満たした際の各技術の導入設備容量, 総コスト，ならびに $\mathrm{CO}_{2}$ 排出量などの情報が出力される仕組みとなっている. 本稿では解析期間を 2010 年から 2050 年とし，この期間における北海道の総 $\mathrm{CO}_{2}$ 排出量を制約条件として，エネルギーシステム構成の変化を解析 した.

\section{$2 \cdot 2$ モデルの設定パラメータと前提条件}

解析対象期間における将来の金銭価值を現在価值に換算する際に用いる割引率を $3 \%$ とし，北海道の人口は各 種統計資料をもとに 2010 年比で 2050 年までに約 3 割減るものとした. 2010 年から 2015 年におけるエネルギー サービス需要は各種統計資料に基づく実績值を与え， 2015 年以降は北海道の人口予測や日本版 MARKAL のべ ースデータ等に基づき設定した（佐藤，2005）。また，燃料価格の推移は，各種統計資料を参考に表 1 のように設 定した (International Energy Agency，2010)。このほか，各種発電設備の利用率等は北海道における実績值に基づ いて設定し，さらに 2010 年と 2015 年における電力供給量は実績值を入力している．以下，本解析に大きく影響 する項目について詳述する.

(1)系統電力発電設備

系統電力の発電設備として本解析モデルに設定しているものは表 2 の通りであり, それぞれ設備導入コスト, 運用・メンテナンスコスト，および寿命を示した. MARKAL モデルの標準的な計算間隔は 5 年間隔となってい るため, 本解析においても 5 年間隔しし, 実質的な計算開始年を 2015 年とした. 解析開始時点で残存している既 存設備は残存寿命をそれぞれに設定した. 原子力発電は 2015 年の時点で発電量をゼロに設定したほか, 本解析は

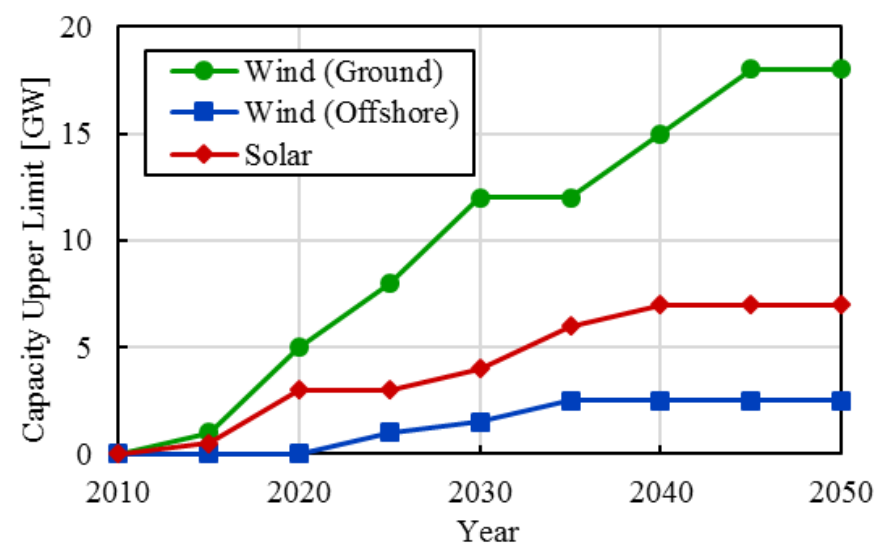

Fig. 1 Given upper-limit of the capacities of wind and solar powers, which is set partially based on the report (Ministry of the Environment, 2011), (Ministry of the Environment, 2015). The wind and solar power do not exceed this upper limit in the analysis. 
Table 3 Installation cost of co-generations (*REH : Ratio of electricity to heat generation. **Total Efficiency : Efficiency when all heat and electricity can be used.)

\begin{tabular}{|c|c|c|c|c|c|c|c|c|c|c|c|c|}
\hline \multirow{2}{*}{ Sector } & \multirow{2}{*}{ Fuel } & \multirow{2}{*}{$\mathrm{REH}^{*}$} & \multirow{2}{*}{$\begin{array}{c}\text { Total } \\
\text { Efficiency } * *\end{array}$} & \multicolumn{9}{|c|}{ Installation Cost $[10,000 ¥ / \mathrm{kW}]$} \\
\hline & & & & 2010 & 2015 & 2020 & 2025 & 2030 & 2035 & 2040 & 2045 & 2050 \\
\hline \multirow{4}{*}{ Industry } & Coal & 1.45 & $55.6 \%$ & 18.0 & 18.0 & 18.0 & 18.0 & 18.0 & 18.0 & 18.0 & 18.0 & 18.0 \\
\hline & Oil & 1.45 & $55.6 \%$ & 18.0 & 18.0 & 18.0 & 18.0 & 18.0 & 18.0 & 18.0 & 18.0 & 18.0 \\
\hline & LPG\&LNG & 1.18 & $73.9 \%$ & 18.0 & 18.0 & 18.0 & 18.0 & 18.0 & 18.0 & 18.0 & 18.0 & 18.0 \\
\hline & LNG & 0.881 & $79.0 \%$ & 42.8 & 36.4 & 29.9 & 28.4 & 26.9 & 26.9 & 26.9 & 26.9 & 26.9 \\
\hline \multirow{2}{*}{ Office } & Oil & 1.45 & $55.6 \%$ & 20.0 & 20.0 & 20.0 & 20.0 & 20.0 & 20.0 & 20.0 & 20.0 & 20.0 \\
\hline & LPG\&LNG & 1.18 & $73.9 \%$ & 20.0 & 20.0 & 20.0 & 20.0 & 20.0 & 20.0 & 20.0 & 20.0 & 20.0 \\
\hline \multirow{2}{*}{ House } & LPG\&LNG & 0.400 & $92.0 \%$ & 22.9 & 22.9 & 22.9 & 22.9 & 22.9 & 22.9 & 22.9 & 22.9 & 22.9 \\
\hline & LPG\&LNG & 0.787 & $84.1 \%$ & 277 & 174 & 70.8 & 70.8 & 70.8 & 70.8 & 70.8 & 70.8 & 70.8 \\
\hline
\end{tabular}

長期的なエネルギー構成を明らかにすることに力点を置いているために，解析期間を通して原子力は運用しない ものとした．ただし，当然ながら原子力を再稼働した場合の解析は種々可能である．また，水力発電と地熱発電 については, 資源量や設備導入可能地等の兼社合いから, 現在導入されている設備量以上の新規導入は無いもの とした. さらに, 過剩な導入速度を抑制するために, 風力発電と太陽光発電の導入可能上限値を, 環境省報告書 (環 境省，2011），(環境省，2015）を参考に図 1 のように設定し，それらがコスト的に有利となったとしても上限值 以上の導入は行われないものとした.

(2)コジェネレーションシステム

産業部門や民生（業務・家庭）部門において, 系統電力とは別な電力供給設備として, 自家用発電を設定して いる. モデルの特性上，これらの発電設備からサービス業種を超えた系統への逆潮流は行われない解析となって いる. 電力と熱を同時に供給するコジェネレーションシステムは, 初期コストの影響で $\mathrm{CO}_{2}$ 排出制限を加えない 場合はあまり導入されないが，排出制限が厳しくなるとその効率の高さから導入されるようになり，解析結果に 大きく影響する. 表 3 に部門別に設定したコジェネレーションシステムの燃料種, 熱電供給比, 設備導入コスト を示した。この中で産業用および家庭用の最下段にある設備費の高いものは燃料電池コジェネであり, 将来的な 設備導入コストの低下を想定した值とした.

(3)エネルギー需要

北海道 MARKAL の需要量は，大別して産業・民生・運輸から構成されている．本解析では主に民生に関して 上述したような人口減少の影響を加味した。一方，産業に関しては製鉄や製紙，農林水産などの北海道内の様々 なものを考慮しているが，いずれもほぼ横ばいの需要量を与えた．運輸に関しては，航空・船舶・鉄道のほか, 自動車部門を旅客と貨物輸送にわけてそれぞれ需要量を与えている。ここで, 自動車による輸送はさらに短距離 需要と長距離需要にわけて設定しており, 自動車旅客・貨物輸送需要のおおよそ 2 割が短距離, 残りが長距離需 要と与えた.

なお，MARKAL モデルではこれらの需要量や供給量を季節ならびに時間帯ごとに与えることが可能であり， 本解析では技術や需要特性に応じて, 夏・冬・中間期の 3 季節と昼夜の 2 時間帯に分けた.

\section{$2 \cdot 3$ MARKAL モデルの改良}

再生可能エネルギーのうち, 太陽光発電は時間変動が規則的で地域間格差が少なく, さらに風力発電に比べて 北海道では導入量がそれほど大きくならないので，平均的な設備利用率を用いて MARKAL 解析に含めた．これ に対して, 風力発電は導入ポテンシャルが高く, 時間変動や季節変動のほか, 地域ごとに風況が異なっている. したがって, 他の設備と同様に季節平均の設備利用率を用いたのでは, 設備導入量が大きくなった場合に実際と 乘離した解析結果となるほか, バックアップ設備量についても過少に評価されることになる，そこで，本解析で は別途参考文献（高橋他，2017）に示寸ような方法で，2014 年における異なった地域ごとの 1 年間にわたる 1 時 間間隔の風況実測データを用い, 再生可能エネルギーの設備利用率や, 供給過剩となって利用できない電力量を 
解析した. この際, 2014 年における電源設備構成をベースとしながら 1 時間ごとの電力需要を与えたほか, 原子 力発電を無くし, LNG コンバインド発電 (LNGCC) を別途調整・バックアップ用に必要量導入する計算とした. 既設の水力発電, 石炭火力および石油火力は運用可能であり, 石油火力は調整用として機能できるものとした. このような条件の基で，風力・太陽光発電による供給電力量を徐々に増加させ， 1 時間ごとの需給バランスを満 足しながら, 発電関連総コストが最小となるように LNGCC の設備量, 既存発電設備の運用量, および風力発電 の最適設置地域を選択するような解析を行った。

図 2(a)は横軸に徐々に増加させた風力発電設備量, 縦軸に風力発電全体の平均設備利用率（供給過剩となった 発電量も含めている）の変化を示したものである．青線はこれまでの MARKAL モデル手法で用いた值であり， 緑線が上述した解析の結果である. 緑線では設備量が増加するにつれて風況の良い地域のオーバーシュート時間 が増大寸るために風力発電の設置地域が分散化され，平均的な設備利用率が徐々に低下寸る傾向となっている. 一方, 図 2(b)は供給過剩となって利用できない電力量を示したものであり, 横軸は年間の全発電量に対する再生 可能エネルギー, 寸なわち水力, 地熱, 太陽光および風力発電による供給割合である. $70 \%$ 再生可能エネルギ 一導入点は図 2(a)の $15 \mathrm{GW}$ に概略相当している. 再生可能エネルギー割合が $50 \%$ を超えると, 大幅に系統需要を 超えた無駄電力が増加することがわかる．こうした解析に合致するように，MARKAL モデル用に作成したモデ ルが赤色の曲線である. この場合はまず, 複数個の設備利用率の異なる風力発電設備を緑の線に概略合致するよ うに用意し, 設備量の増加に応じて利用率の高いものから順に選択するようなモデルとした. これによって, 風 力発電設備が多量に導入された際の年間平均設備利用率の変化を表現できるようにした．さらに，発電変動に関 連するパラメータを入れることによって, 年間電力使用量に占める再生可能エネルギーの割合に応じて変化する 無効電力（供給オーバーによって余剩となった電力）を表現できるようにした. 図 2(b)は供給過多となった無効 電力を示したものであり，本手法によって概略 MARKAL モデルを用いてサブモデルの解析結果（緑線）を表現 できていることがわかる. なお, 赤色の線が再生可能エネルギー導入率 $70 \%$ 付近において不連続な挙動を示して いるが，これは MARKAL モデル内の電力需要制約による干渉を受けて生じたふらつきである. 以上より，本手 法によって特に風力発電の設備量が大きくなった際の設備利用率の低下ならびに余剩電力の発生量を比較的よく 表現できたといえる.

なお，風力発電設備が増大しても供給不足となる時間のためのバックアップ電力設備が必要である，そのため に, 風力発電設備量に応じて必要最小の LNGCC バックアップ電源量を設定した. これにはバックアップ用 LNGCC の時間応答性等を考慮したサブモデルによる解析結果を参考に, 風力および太陽光発電の年間合計発電 量の $18 \%$ 以上の年間発電量を供給できる設備量を LNGCC の下限值として与えた. このような設定で, 2014 年に おける 1 時間間隔の発電変動においても電力不足とならないことを確認した. 特に風力発電は太陽光発電と異な って地域間の差異が大きく, 風力の弱、時間でもどこかで風車が発電している特徴を有していた. さらに, コス 卜影響の少ない比較的わずかな蓄電池を設備することで, 短時間のバックアップ能力を格段に向上できることも,

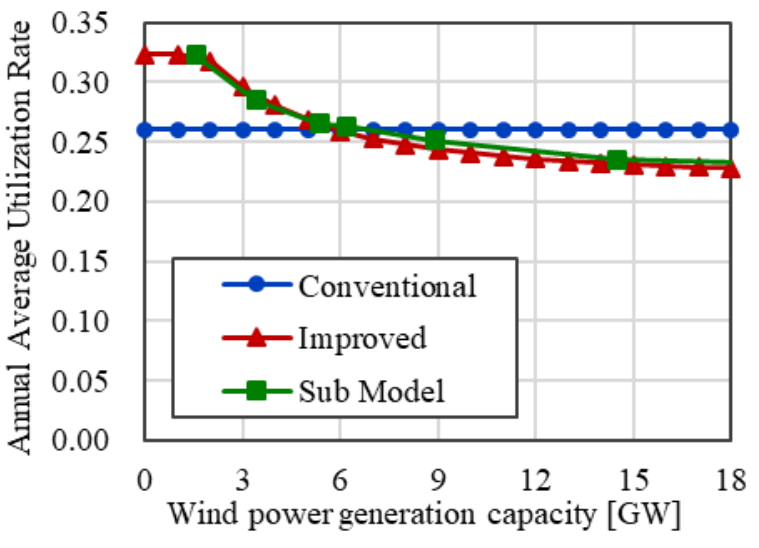

(a) Utilization rate of wind power for the total capacity

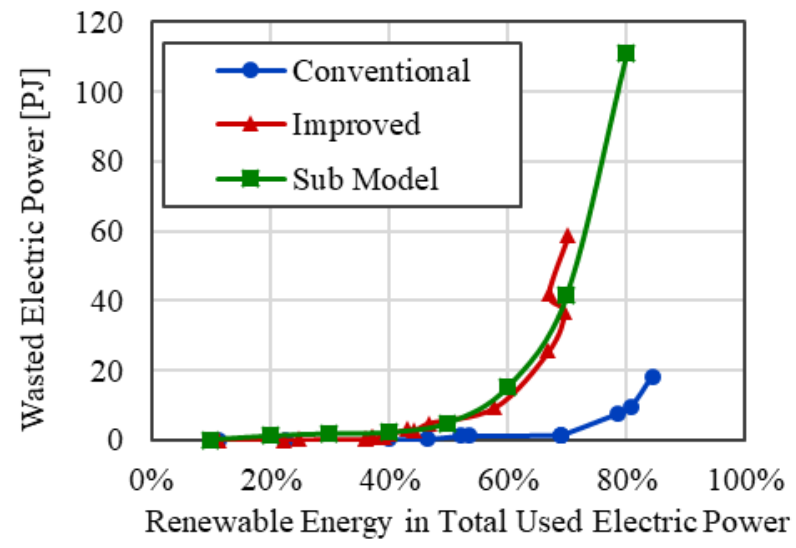

(b) Over-generated power for the increasing renewable energy

Fig. 2 Improved simulation model compared to the conventional MARKAL model. The green line, Sub Model, is the result obtained by the precise model analysing the optimal wind power selection for the fluctuating actual data in Hokkaido (Takahashi et. al, 2017). 
前記研究の中で確認した（高橋他，2017）。その意味で，本解析条件は非常に特異な気象とならない限り，電力供 給不足にならない設定となっている，ただし，完全に停電確率をゼロに近づける場合には，風力や太陽光発電以 外の電源設備によって最大電力需要を賄う必要が生じる. この点, 設備利用率とコストの兼衫合いから非常時の 設備形態に関する議論が別途必要といえる. 本研究は, 上述した条件でバックアップ電力を設定した解析となっ ている.

\section{3. 解析結果および考察}

\section{$3 \cdot 1 \mathrm{CO}_{2}$ 制約による $\mathrm{CO}_{2}$ 排出ならびにコスト変化}

本解析では, 2010 年から 2050 年までの $\mathrm{CO}_{2}$ 総排出量に対する制約を与え, その条件を満たしながら総コスト が最小となる設備構成が解として求められる. 図 3 は解析の結果得られた $\mathrm{CO}_{2}$ 量の年間排出量の変化を示したも のであり, 図 4 はそれに対する解析期間全体の総コストの変化率である. 図において 2010 年から 2015 年にかけ て $\mathrm{CO}_{2}$ 排出量が増加しているが，これは 2011 年 3 月の東日本大震災に伴って生じた電源構成の変化によるもの である. まず, $\mathrm{CO}_{2}$ 排出量に制約を与えない場合でも 2030 年以降の排出量が減少している. これは人口減に伴う エネルギー消費の減少に加えて, 各種設備の効率向上によるものである. これをベースとして, 期間全体の $\mathrm{CO}_{2}$ 排出量 (以後, 積算削減率と呼ぶ) に制約を加えると, 実質的な解析開始時期である 2015 年から早々に $\mathrm{CO}_{2}$ 量 が減少し, 特に早い時期の変化が顕著となっている. これは, 比較的早期に $\mathrm{CO}_{2}$ 排出量の少ない設備を導入した 方が，少ないコストで $\mathrm{CO}_{2}$ を長い期間にわたって減少できることによるものである. 2050 年の削減目標を設定し た場合，低コストで有効な技術が登場するまで新技術の導入を先延ばししがちと思うが，長期的なコストと有効 な $\mathrm{CO}_{2}$ 削減効果を考えた場合には，できるだけ早期に $\mathrm{CO}_{2}$ 削減を実行するのが適切であることがわかる.

$\mathrm{CO}_{2}$ 削減制約を徐々に増加させると $38 \%$ で限界となり，それ以上の削減は困難であった．これは図 4 に示され るように，コストを大幅に増加させても有効に $\mathrm{CO}_{2}$ を削減できる技術の導入が困難となることによる．この場合 の 2050 年における $\mathrm{CO}_{2}$ 削減量は, 表 3 において後述するように, 2015 年度比 $63.5 \%$ 減となっている. これは次 節で詳述するが, 本解析条件では産業部門と運輸部門において, $\mathrm{CO}_{2}$ 削減に有効な技術に限界があるためである.

なお, 図 4 に示されるように $\mathrm{CO}_{2}$ 削減割合が上昇するにつれてコストの増加割合が徐々に高くなっており, $20 \%$ 程度の $\mathrm{CO}_{2}$ 削減を行うためには $3 \%$ 程度のコスト増加であるのに対して, $30 \%$ の削減ではコストが $8 \%$ 増となるこ とがわかる.ちなみに, 2050 年における対 2015 年度の $\mathrm{CO}_{2}$ 削減割合は, $20 \% の \mathrm{CO}_{2}$ 積算削減制約の場合 $47.1 \%, 30 \%$ の場合 $57.0 \%$ とっている.

以上より，比較的少ないコストで長期間にわたる $\mathrm{CO}_{2}$ を有効に減らすにはできるだけ早期に $\mathrm{CO}_{2}$ 削減に有効な 設備を導入すべきであり，3\%程度のコスト増で期間全体の $\mathrm{CO}_{2}$ を約 $20 \%$ 削減できること，その際の 2050 年にお ける対 2015 年度比の $\mathrm{CO}_{2}$ 削減割合は $47 \%$ 程度となることがわかった。 また, 2050 年における対 2015 年度比の $\mathrm{CO}_{2}$ 削減割合を $64 \%$ 以上にするには，本解析の条件を超えた何らかの技術導入が必要であることがわかった.

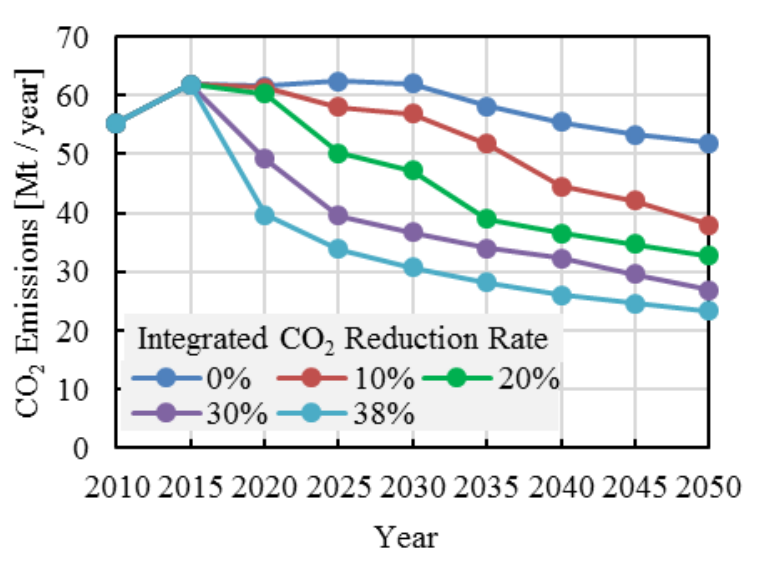

Fig. $3 \mathrm{CO}_{2}$ emissions for the reduction constraints. The $\mathrm{CO}_{2}$ starts to decrease from the early stage for the constraints to have smaller cost for the period. The maximum limit of $\mathrm{CO}_{2}$ reduction was $38 \%$.

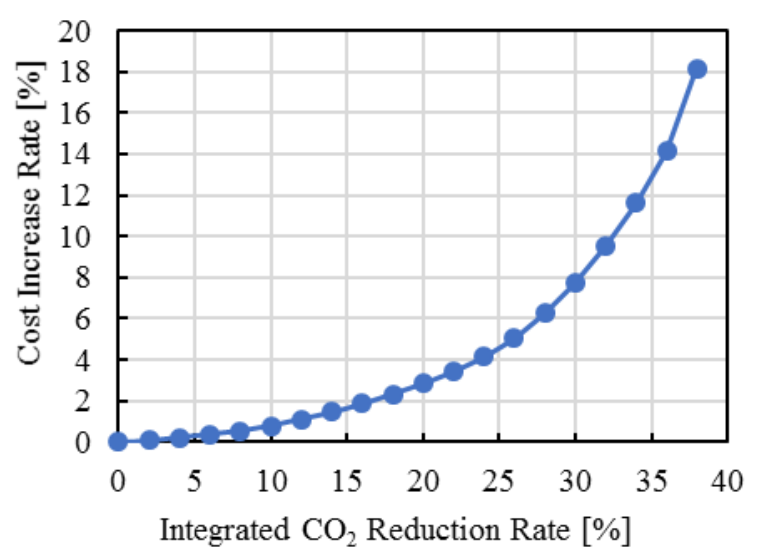

Fig. 4 Cost increase rate for the integrated $\mathrm{CO}_{2}$ reduction rate. The cost increase rate is $3 \%$ for the $\mathrm{CO}_{2}$ reduction rate of $20 \%$, whereas the reduction rate reaches a limit even with significant cost increase. 


\section{$3 \cdot 2$ 部門別 $\mathrm{CO}_{2}$ 排出量変化}

図 5 は $\mathrm{CO}_{2}$ 積算削減率を $0 \%, 20 \% ， 30 \% ， 38 \%$ の 4 通りに設定した際の, 部門別 $\mathrm{CO}_{2}$ 排出量を示したもので ある.この際分類した部門は, 農林水産業, 産業, 民生（業務）, 民生（家庭）, 運輸の 5 つとした. また，表 4 に $\mathrm{CO}_{2}$ 積算削減率のそれぞれに対して，2050 年における対 2015 年比の削減割合をまとめた。図および表から， 積算削減率を高くするほど，特に民生部門や産業部門において $\mathrm{CO}_{2}$ 排出量が大きく変化することがわかる．これ は主に系統電力における $\mathrm{CO}_{2}$ 排出量の減少がこの部門で大きく影響したことが要因である。これに対して, 運輸 部門では $\mathrm{CO}_{2}$ 制約の影響がわずかに見られるものの，その差異は比較的小さく，農林水産業部門では排出量制約 による変化はほとんど見られない. なお， $\mathrm{CO}_{2}$ 積算削減率を $38 \%$ とした場合，産業部門の 2020 年以降の量が横ば いとなっているが，これは主として製鉄業や製紙業における $\mathrm{CO}_{2}$ 排出によるものである.

以上より, $\mathrm{CO}_{2}$ 積算削減率を最大にした場合には民生および産業部門で顕著に $\mathrm{CO}_{2}$ 排出量が減少するが, 運輸, 農林水産業，および製鉄・製紙部門からの $\mathrm{CO}_{2}$ がそれほど低下せず，その削減限界に大きく影響していることが わかった。

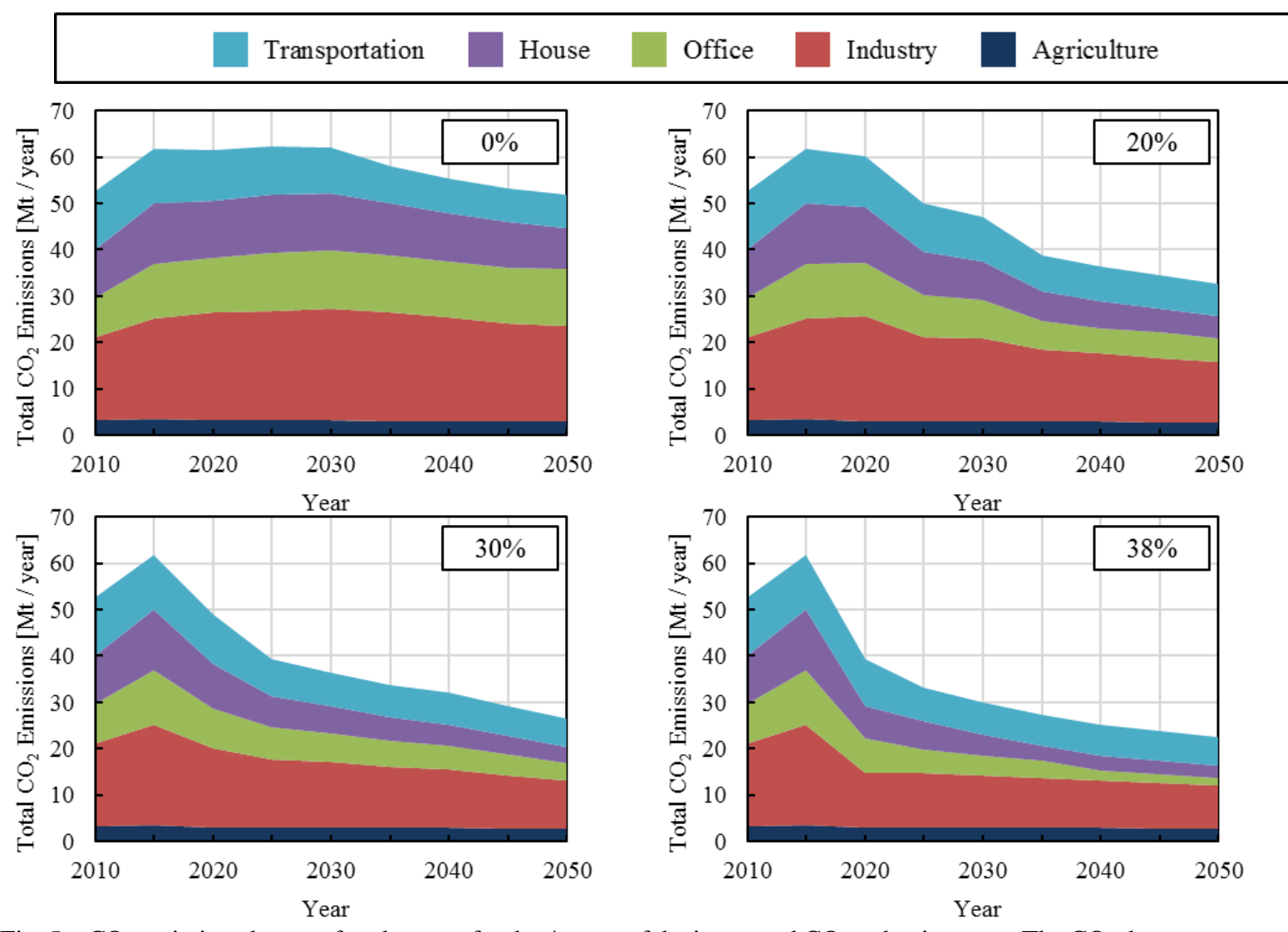

Fig. $5 \mathrm{CO}_{2}$ emission change of each sector for the 4 cases of the integrated $\mathrm{CO}_{2}$ reduction rates. The $\mathrm{CO}_{2}$ decreases significantly in civilian and industrial sectors. However limited amount of $\mathrm{CO}_{2}$ remains in steel and paper industries and for driving powers in industry. Emissions in transportation is less-affected by the constraints.

Table 4 Reduction rates of $\mathrm{CO}_{2}$ in 2050 relative to 2015

\begin{tabular}{|c|c|c|c|c|c|}
\hline \multicolumn{2}{|c|}{ Integrated $\mathrm{CO}_{2}$ reduction rate } & $0 \%$ & $20 \%$ & $30 \%$ & $38 \%$ \\
\hline \multicolumn{2}{|r|}{ Whole Hokkaido } & $16.2 \%$ & $47.1 \%$ & $57.0 \%$ & $63.5 \%$ \\
\hline \multirow{5}{*}{ 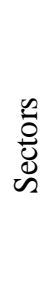 } & Transportation & $38.6 \%$ & $41.1 \%$ & $46.8 \%$ & $47.7 \%$ \\
\hline & House & $32.0 \%$ & $63.2 \%$ & $74.2 \%$ & $79.5 \%$ \\
\hline & Office & $-2.7 \%$ & $56.7 \%$ & $68.3 \%$ & $85.4 \%$ \\
\hline & Industry & $5.3 \%$ & $40.1 \%$ & $52.3 \%$ & $57.6 \%$ \\
\hline & Agriculture & $13.4 \%$ & $17.6 \%$ & $17.6 \%$ & $17.6 \%$ \\
\hline
\end{tabular}




\section{$3 \cdot 3$ 系統電力の発電設備および発電量の構成変化}

次に，部門横断的にエネルギー消費を見た場合に極めて重要となる電力系統に関して，本節で詳述する．本研 究では前述したように, 現在停止している原子力発電は 2015 年以降も引き続き発電を行わないものとした. また,

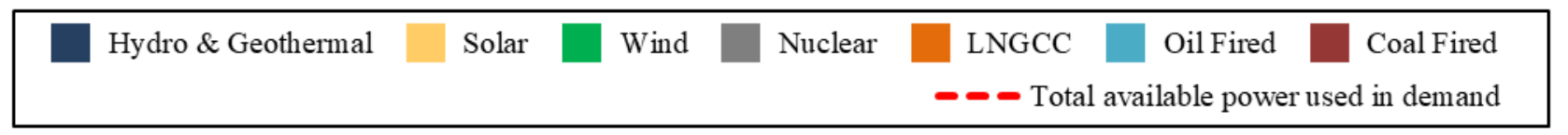
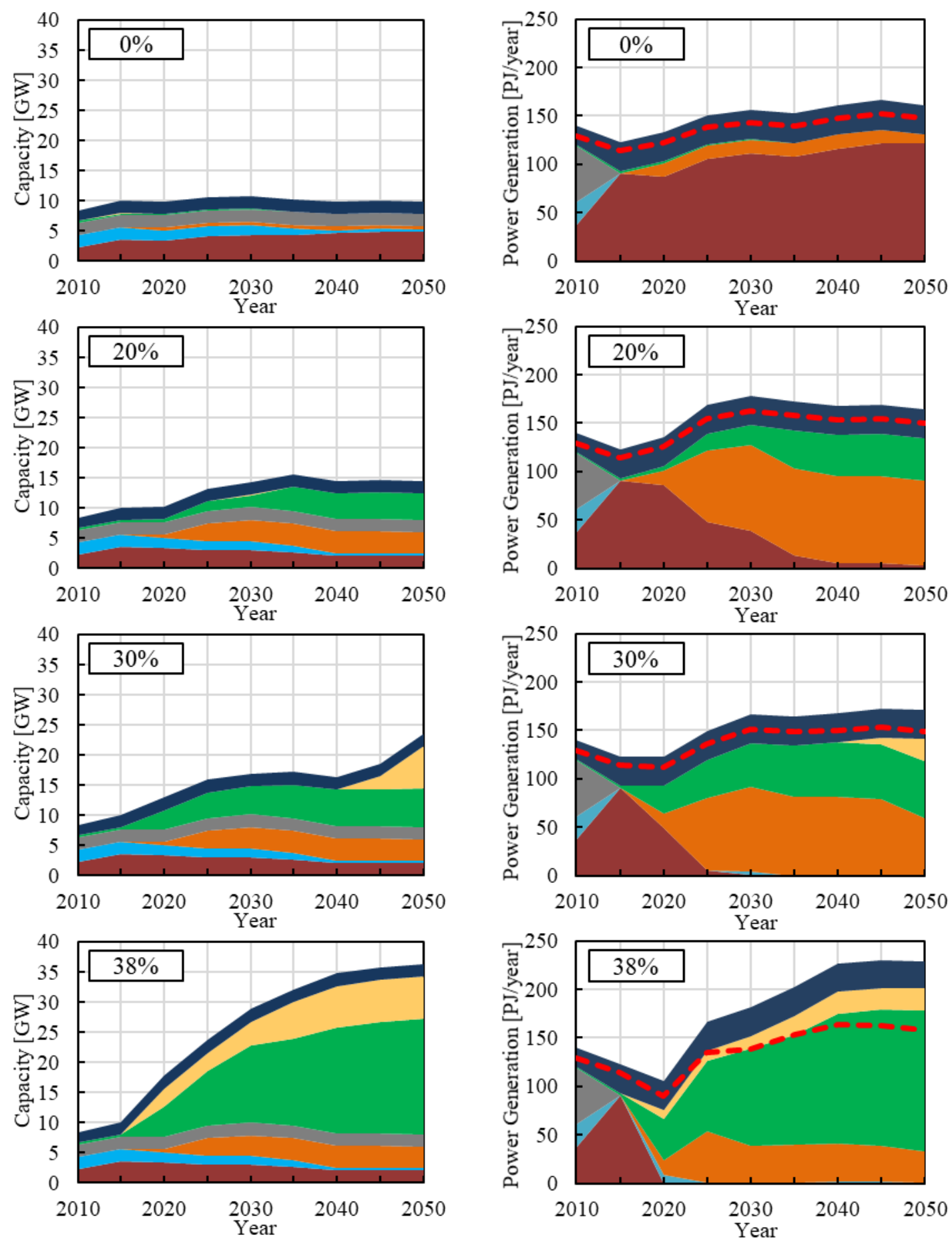

(a) Equipment capacity

(b) Amount of power generation

Fig. 6 Structure of grid power plant capacities and generated powers for the different $\mathrm{CO}_{2}$ reduction constraints. Increased $\mathrm{CO}_{2}$ reduction rate drives significant increase in wind and solar power, and excessive power over the demand (dashed line) becomes large. LNG combined cycle becomes backup power at $\Delta \mathrm{CO}_{2}$ of $38 \%$. 
LNG コンバインドサイクル発電については，既に建設が開始されている石狩湾新港発電所 1 号機（2015 年 8 月 着工，2019年 2 月商業運転開始予定，56.9 万 $\mathrm{kW}$ ）を下限值として設定した. これに加えて LNG コンバインド サイクル発電には，変動の大きな再生可能エネルギーに対するバックアップ電源としての機能も付与することと し，2・3 節で述べたサブモデルから導出した下限值を下回らないように設定した.

図 6 は系統内の発電種別ごとにおいて，(a)設備容量（左図）と(b)年間発電量（右図）を， $\mathrm{CO}_{2}$ 積算削減率別に 示したものである. 図ではいずれの場合も発電はしていないものの原子力発電設備が残存している表示となって いる.また，水力ならびに地熱発電は現状のままの設備が維持されており，比較的大きな電力が変わらずに供給 されている. なお，図6(b)中に示した赤破線は有効に消費された電力量であり，それを上回った発電は送電系統 等におけるロスのほか, 再生可能エネルギーにより過剩に発電した電力に相当している（実際には系統から解列 されて発電しないが, 発電ポテンシャルとして表示している).

まず， $\mathrm{CO}_{2}$ 積算削減率 $0 \%$ の場合には，割高な石油火力が減少し，代わりに石炭火力が増大している，一方， 2019 年に導入された LNG コンバインドサイクル発電が一定の発電を維持している. その結果，右図に示すよう に約 $80 \%$ 電力が石炭火力から供給される結果となっている. これに対して $\mathrm{CO}_{2}$ 積算削減率を $20 \%$ にする, 風 力発電ならびに LNG コンバインドサイクル発電の増加が顕著となり, 石炭火力による発電が徐々に減少してい くことがわかる. 特に LNG コンバインドサイクルによる発電量の増加が極めて大きくなっている. また，総発 電量も積算削減率 $0 \%$ の場合に比べて増大しており，低 $\mathrm{CO}_{2}$ 排出となった電力の利用が進むことがわかる．この ように $\mathrm{CO}_{2}$ 排出量に $20 \%$ 程度の制約を加えると, 電源設備構成は顕著に変化する. それでもその際の解析期間中 の総コストは, 図 4 で示したように約 $3 \%$ 程度の増加にとどまっている. さらに $\mathrm{CO}_{2}$ 削減率を増大させ $30 \%$ にす ると, LNG コンバインドサイクル発電設備はあまり変わらずに, 風力発電が顕著に増加するほか, 太陽光発電が 2040 年ころから大きく増加する結果となっている. 一方, 石炭火力は設備が残存するものの, 2025 年以降は殆ど 発電しない状態となっている.さらに $\mathrm{CO}_{2}$ 積算削減率を限界に近い $38 \%$ こまですると, 大幅に風力ならびに太陽 光発電が早期から増加し, 最終的には $35 \mathrm{GW}$ 程度の総発電設備量となっている.この大きな再生可能エネルギー の導入に対して調整能力を保つために, 石油火力発電が LNG コンバインドの設備増加期間を補完し，2025 年ま で発電が継続している. また, LNG コンバインドサイクルは削減率 $30 \%$ の場合と同程度の設備量となっているも のの発電量は顕著に減少しており, 再生可能エネルギーのバックアップ電力としての運用が顕著となっているこ とがわかる. さらに, 実際に利用された電力量線 (赤破線) を越えて発電量が増加しており, 再生可能エネルギ 一設備の大量導入によって余剰となる電力が顕著に増大していることがわかる. 本解析ではこの余剩電力を水素 変換して利用する等のシステムを入れておらず，そうした技術導入の余地を示している．なお， $\mathrm{CO}_{2}$ 積算削減率 が 38\%程度まで高くなると, 2020 年前後の発電量がむしろ低下しており，この傾向は削減率が 30\%でもわずかに 現れている，これは後述するように，民生部門においてガスコジェネレーションの導入がこの時期に大量に生じ ることによるものである.

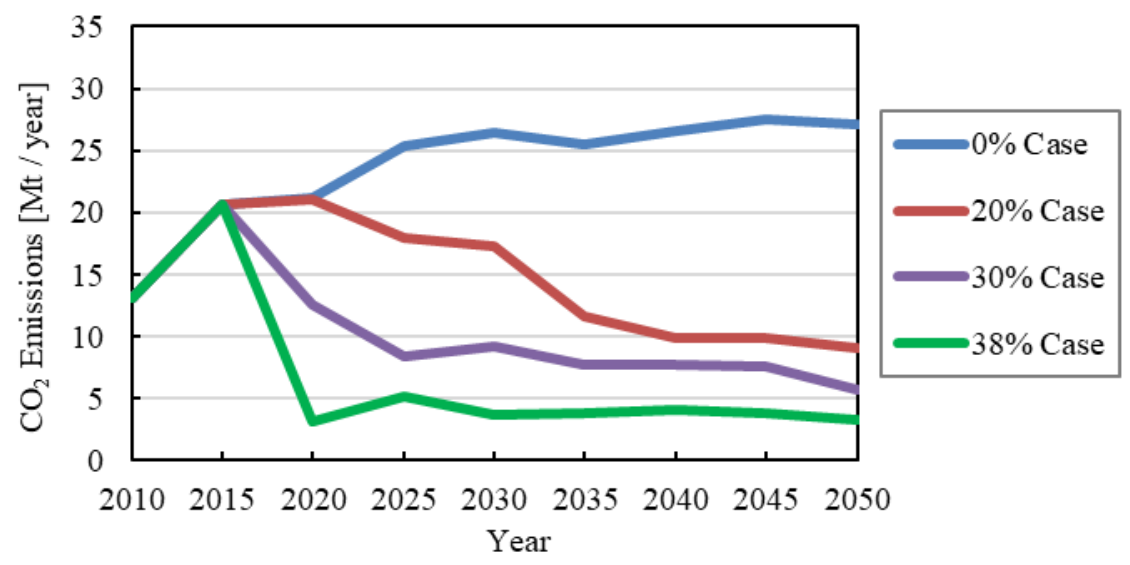

Fig. $7 \mathrm{CO}_{2}$ Emissions from grid power plants. As the $\mathrm{CO}_{2}$ reduction rate increases, the $\mathrm{CO}_{2}$ emission from grid power decreases significantly, even though the generated power becomes larger at $\Delta \mathrm{CO}_{2}$ of $38 \%$ as seen in Fig. 6. 
次に図 7 は, 系統電力発電によって排出される $\mathrm{CO}_{2}$ 排出量を示したものである. $\mathrm{CO}_{2}$ 積算削減率を高くするほ ど顕著に $\mathrm{CO}_{2}$ 排出量が減少しており，全体量における発電部門の寄与が大きいことがわかる．特に総発電量が増 加しているにも関わらず $\mathrm{CO}_{2}$ 排出量が減少しており, 再生可能エネルギーによる効果が示されている. $\mathrm{CO}_{2}$ 積算 削減率を $38 \%$ にした場合でも $\mathrm{CO}_{2}$ 排出量はゼロになっていないが，これはバックアップ電力からの $\mathrm{CO}_{2}$ による ものである．この際の電力部門における $\mathrm{CO}_{2}$ 積算削減量は北海道全体で削減する積算量の約 $78 \%$ （積算削減率 $38 \%$ のうち約 $30 \%$ 分に相当し, 残りの約 $8 \%$ は各部門での機器更新や燃料転換等による $\mathrm{CO}_{2}$ 削減)を占めており, 北海道における $\mathrm{CO}_{2}$ 排出削減に対して極めて大きな影響を与えている.

以上より，エネルギー消費系全体に対して $\mathrm{CO}_{2}$ 削減制約を与えると電力部門の低炭素化が大きく進行し，石炭 火力の運用が縮小寸る一方, $\mathrm{LNG}$ コンバインド発電ならびに風力発電の増加が顕著になる. さらに $\mathrm{CO}_{2}$ 積算削減 制約を $30 \%$ 以上にすると, LNG コンバインドの設備量は変わらずに風力ならびに太陽光発電が顕著に増加し, LNG コンバインドは再生可能エネルギーのバックアップ電源としての役割が大きくなる. 積算削減率が $38 \%$ 近く になると, 2020 年までに電源部門における低炭素化が顕著に進行し, その後も引き続き風力ならびに太陽光発電 設備の増加が進行するものの, バックアップ電源である $\mathrm{LNG}$ コンバインド発電からほぼ一定量の $\mathrm{CO}_{2}$ が排出さ れる. この場合, 需要を上回る発電量が次第に大きくなっており，この余剩電力の新たな利用技術の導入が，さ らなる $\mathrm{CO}_{2}$ 削減の鍵といえる.

\section{$3 \cdot 4$ 部門別エネルギー消費形態の変化}

前節では部門横断的な視点で電力系統のエネルギー供給構成の変化を示したが，本節では部門別に電力をはじ めとした各種エネルギーの消費形態と $\mathrm{CO}_{2}$ 排出削減に対する各種技術の寄与度を分析する.

(1) 産業部門

図 8 に産業部門におけるエネルギー消費構成の変化を示した. 各図の右上の数字はこれまでと同様に $\mathrm{CO}_{2}$ の積 算削減率を表す，積算削減率が $0 \%$ 場合は石炭の占める割合が高く，そのほかに重油や軽油が多く用いられて いる. また, エネルギー消費に占める電力の割合は概略 20\%程度となっている. 黒液は一定量が利用されており, その量は条件や年代によらず一定となっている，これに対して， $\mathrm{CO}_{2}$ 積算削減率を $38 \%$ まで高くした場合には石 炭の利用が早期に減少し, 2020 年以降は概略一定となっている. これは自家発電用に用いられていた石炭が 2020 年までに系統電力およびガスコジェネに置き換わり, 主として製鉄部門で利用される石炭が 2020 年以降に残って いることによるものである. 2020 年までに系統電力消費が急増しているのはこのためである. 一方, 重油ならび に軽油の利用はほぼ一定となっており，製鉄所や製紙産業のボイラーのほか，一部の動力に用いられている。一 方, LPG および LNG の利用が増大しており, 石炭の代わりに自家発電や必要な熱供給に利用されている. 産業 部門において削減された $\mathrm{CO}_{2}$ の大部分は自家発部分と関連しており, 従来行われていた石炭による自家発電が系 統電力やガスエンジンコジェネに置き換わったことによるといえる.
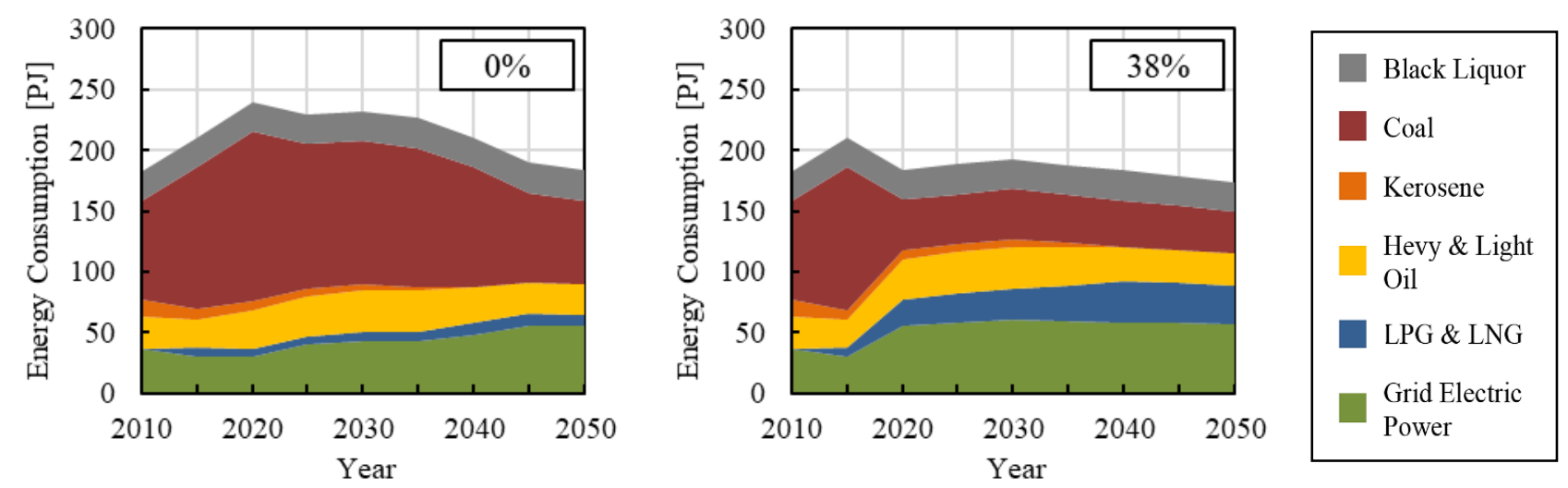

Fig. 8 Energy consumption structure in industrial sector for the two $\mathrm{CO}_{2}$ reduction constraints of $0 \%$ and $38 \%$. When the $\mathrm{CO}_{2}$ reduction constraint becomes $38 \%$, the coal used for the factory power-generation decreases in early stage and the part of it is shifted to gas utilization. Limited amount of coal remains in steel and paper industries. 

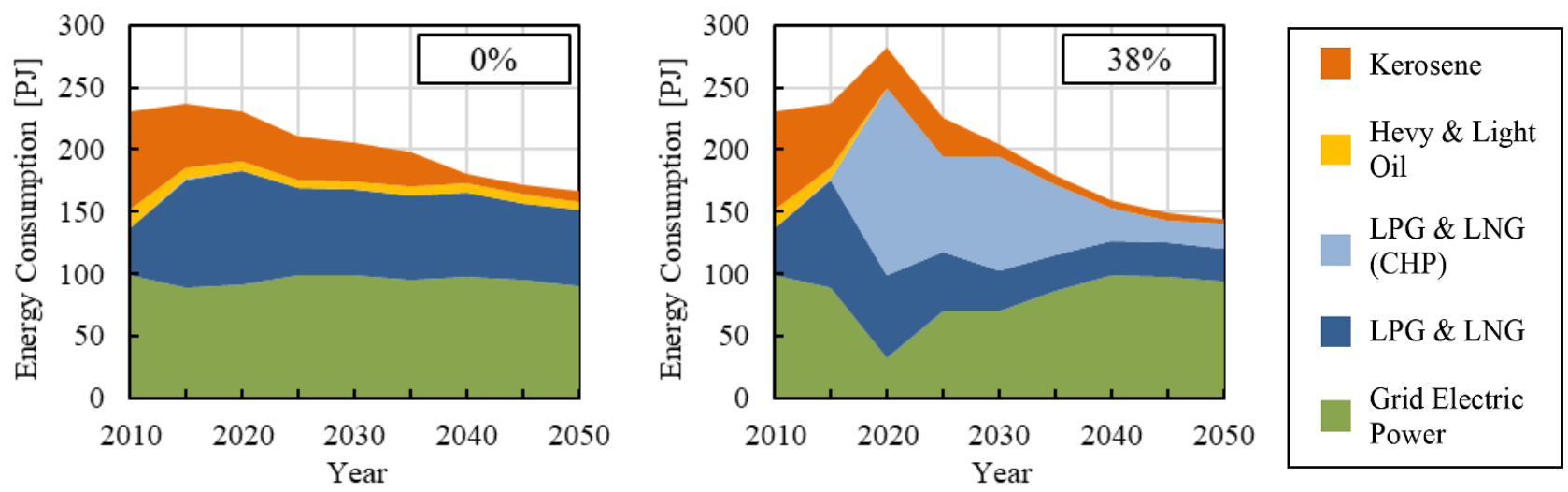

Fig. 9 Energy consumption structure in consumer sector for the two $\mathrm{CO}_{2}$ reduction constraints of $0 \%$ and $38 \%$. At the constraint of $38 \%$, gas usage for CHP significantly increases particularly around 2020 , when $\mathrm{CO}_{2}$ level in grid is still high, then it decreases later due to the decreased $\mathrm{CO}_{2}$ in grid and selection of heat pump.

以上より， $\mathrm{CO}_{2}$ 削減量を最大化した場合には製鉄や製紙ならびに動力等のエネルギ一代替が困難な部門で石炭 や重油の消費が残るといえる.

(2) 民生部門（業務部門と家庭部門）

電力ならびに暖房や給湯が主な需要である民生部門では, $\mathrm{CO}_{2}$ の積算削減率に応じて大幅に $\mathrm{CO}_{2}$ 排出量が変化 するのは前述したとおりである．図 9 は民生部門におけるエネルギー消費構成の変化を $2 つ の \mathrm{CO}_{2}$ 積算削減率に おいて示したものである. 各図の右上の数字はこれまでと同様に $\mathrm{CO}_{2}$ の積算削減率を表す．この際，LPG\&LNG についてはコジェネレーションシステム (CHP) によるものと, それ以外の消費に分けて示した. $\mathrm{CO}_{2}$ 積算削減 率が 0\%の場合は 2015 年以降の系統電力消費ならびに LPG および LNG の消費が概ね一定となっている一方，灯 油の利用が徐々に減少している，これは人口減少を考慮すると，暖房・給湯用の灯油がガスやヒートポンプ用の 系統電力に次第に置き換わっていることを示している.これに対して $\mathrm{CO}_{2}$ 積算削減率を $38 \%$ とた場合には 2020 年までに急激にガスコジェネレーションが増加し，その後徐々にそれが系統電力に置き換わっていく．それに伴 って, 系統電力の消費が一時的に減少している. ガスコジェネレーションが一時的に増加するのは, 低 $\mathrm{CO}_{2}$ の系 統発電設備の建設が追い付かず，その間に比較的寿命の短いガスコジェネレーションを導入することが $\mathrm{CO}_{2}$ の削 減に効果的であったためである. その後は風力や太陽光発電が系統電力の中で徐々に増加するため, 相対的に $\mathrm{CO}_{2}$ 排出の高いガスコジェネレーションが系統電力に置き換えられていく.

なお，このような 2020 年前後の一時的なコジェネレーションの増加現象は，積算削減率が $26 \%$ 超えるあた りから見え始め, 図 4 におけるコスト増加曲線に対応している。このコスト増加はこうした要因以外に, 利用で きない余剩電力の増加によるところも大きく，余剩電力を利用した水素製造とそのコジェネレーション利用を行 うならば，さらに効果的に $\mathrm{CO}_{2}$ 量を削減できる可能性がある。ただし，それは導入技術のコスト次第であり，今 回はそうした解析は含めていない.

(3) 運輸部門

北海道の運輸部門におけるエネルギー消費は，その 7 割以上を自家用・業務用を含めた自動車によって占めら れており，残りが鉄道や航空および船舶となる．そのため，運輸部門の $\mathrm{CO}_{2}$ 排出量の変化は主に自動車の車種構 成の変化によって生じる，ここで，MARKAL モデルでは自家用乗用，自家用貨物，業務用旅客，業務用貨物の それぞれに対して車種ごとの車両価格や燃料消費量がデータとして与えられ，最小コストで需要を満たすように 計算されている.ただし, 新型車の導入割合には上限值を与え, 急激に変化し過ぎないような計算となっている. 図 10 に北海道の自家用乗用自動車の車種構成変化を示寸. 縦軸の単位（B v-km）は，台数 $\mathrm{x}$ 走行距離を Billion 台・ $\mathrm{km}$ 単位で表現したものである. $\mathrm{CO}_{2}$ の積算削減率が $0 \%$ ケースにおいても，2025 年から 2035 年の 10 年間で ハイブリッド自動車が急速に導入されている. そのために自家用乗用車部門の $\mathrm{CO}_{2}$ は減少することになる.ただ し，業務部門では全てディーゼルエンジンのままであった。一方， $\mathrm{CO}_{2}$ の積算削減率を $38 \%$ とた場合には 2015 年からハイブリッド車の導入が始まっている.さらに 2,020 年ころから電気自動車が導入されているが，4 分の 1 

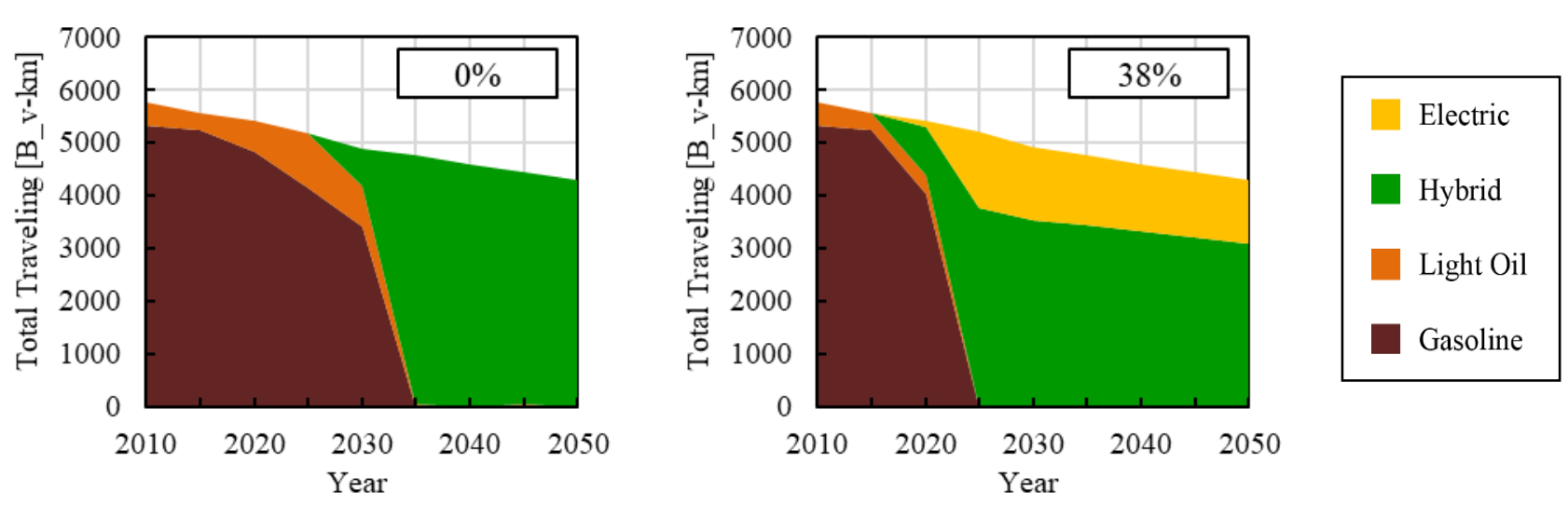

Fig. 10 Structure of vehicle types in passenger cars. When the $\mathrm{CO}_{2}$ reduction constraint is high, hybrid vehicles increase earlier and electric vehicles appear for the cars with limited driving distance. However, there was no change in large commercial vehicles, and this is the reason of little difference in Fig. 5 regardless of the $\mathrm{CO}_{2}$ constraints.

程度の割合にとどまっている。これは電気自動車が自動車輸送需要の約 2 割を占める短距離輸送需要しか満たせ ないように，MARKAL 計算において設定したためである．業務用旅客部門ではわずかにハイブリッド車および 電気自動車が 2030 年以降に導入されていたが，業務用貨物では全てディーゼル車のままであった.

ここで図 5 を見ると，運輸部門における $\mathrm{CO}_{2}$ の変化は 2030 年以降わずかに減少しており， $\mathrm{CO}_{2}$ の積算削減率 を 30\%以上にした場合には 2020 年頃から減少が見られ，上記と対応していることがわかる．ただし，その差異 はそれほど顕著なものとはなっていない。これは $\mathrm{CO}_{2}$ 制約によらずハイブリッド車がいずれの場合も普及するこ と, 従来型自動車の効率も向上しており，ハイブリッド自動車もガソリンを利用していることから両者の差がそ れほど大きくはないこと，運輸部門全体に占める自家用乗用車の割合が低いことなどが影響している.

以上より, 運輸部門では自家用乗用車が 2030 年前後に顕著にハイブリッド自動車に置き換わるが, 業務用自動 車，鉄道，航空および船舶部門における変化はほとんどないために， $\mathrm{CO}_{2}$ 削減制約にかかわらず全体的な変化は 比較的小さいといえる.この部門で $\mathrm{CO}_{2}$ をより顕著に減らすためには業務部門を含めた自動車のゼロエミッショ ン化が必要であり, 例えば余剩電力を利用した水素製造と燃料電池自動車の組合せなどが有効と考えられる.

\section{4. 結 論}

エネルギー部門の最適化解析プログラムである MARKAL モデルを変動の大きな再生可能エネルギーにも適用 できるように修正を行った上で, 北海道の 2010 年から 2050 年に亘る積算 $\mathrm{CO}_{2}$ 排出削減割合に対する社会総コス トおよび最適エネルギーシステム構成に関する解析を行った．得られた結論は，以下の通りである：

1. 比較的少ないコストで長期間にわたる $\mathrm{CO}_{2}$ を有効に減らすには，できるだけ早期に $\mathrm{CO}_{2}$ 削減に有効な設備 を導入すべきであり，3\%程度のコスト増で期間全体の $\mathrm{CO}_{2}$ を約 $20 \%$ 削減できること，またその際の 2050 年にお ける対 2015 年度比の $\mathrm{CO}_{2}$ 削減割合は $47 \%$ 程度となることがわかった. また, $\mathrm{CO}_{2}$ の積算削減率は $38 \%$ 程度が限 界であり，その際の 2050 年における対 2015 年度比の $\mathrm{CO}_{2}$ 削減割合は 64\%程度になると見込まれた。 これ以上に $\mathrm{CO}_{2}$ を削減するには，再生可能エネルギー大量導入時の余剩電力を有効利用するなど，本解析に含めていない新 たな技術の導入が必要である.

2. エネルギー消費系全体に対して $\mathrm{CO}_{2}$ 削減制約を与えると電力部門の低炭素化が大きく進行し，石炭火力が 縮小寸る一方， LNG コンバインド発電ならびに風力発電の増加が顕著になる．さらに $\mathrm{CO}_{2}$ 積算削減制約を $30 \%$ 以上に高くすると, LNG コンバインドの設備量は変わらずに風力ならびに太陽光発電が顕著に増加する一方, LNG コンバインドは再生可能エネルギーのバックアップ電源としての役割が大きくなる.

3. $\mathrm{CO}_{2}$ 積算削減制約を大きくすると民生部門で顕著に $\mathrm{CO}_{2}$ 排出量が減少し, 暖房・給湯用の灯油がガスコジ ェネレーションや電力によるヒートポンプに次第に置き換わる。一方，産業部門では主として石炭を用いた自家 発電が減少し低炭素化が進むが, 製鉄や製紙ならびに動力等の技術代替が困難な部門で石炭や重油の消費が残る. 
運輸部門では自家用乗用車が 2030 年前後に顕著にハイブリッド自動車に置き換わるが，業務用自動車，鉄道，航 空および船舶部門における変化は少なく, 自動車部門の一層の電動化および燃料電池自動車の増加が必要である.

以上の結果は，用いたデータ条件によって大きく変化すると通常考えられがちである．そこで，感度が高 いと思われるデータを適当な範囲で増減させてみたが, 主たる結論は変わらなかった. 本解析条件から大き く異なった技術やコストが導入されない限り，本結論はそれほど変わらないものと考えられる.

\section{謝 辞}

日本原子力研究開発機構が約 30 年にわたって開発してきた日本版MARKALデータを提供いただいたことに謝 意を表する．また，本研究は当該研究室における長年の作業蓄積に基づいて行われたものである．最初に MARKAL モデルの導入を助言いただいた菱沼孝夫前北大教授，現在筑波大学にいる鈴木研悟助教の他，多数の 関係された北大大学院卒業生に謝意を表する.

\section{文献}

秋元圭吾, 佐野史典, パリ協定 $2^{\circ} \mathrm{C}$ 目標から見た我が国の 2050 年排出削減目標に関する分析, 電子ジャーナル「エ ネルギー・資源学会論文誌」, Vol.38, No.1 (2017).

International Energy Agency, World energy outlook 2010 (2010), available from <http://www.env.go.jp/earth/report/h23-03/index.html >, (参照日 2017 年 9 月 30 日).

Komiyama, R. and Fujii, Y., Optimal integration of variable renewables in electric power systems of Japan, Journal of Energy Engineering, Vol.143, Issue 3 (2017).

Loulon, R., Goldstein, G. and Noble, K., Documentation for the MARKAL family of model (2004).

環境省, 再生可能エネルギー導入ポテンシャル調査報告書 (2011), available from <http://www.env.go.jp/earth/report/h23-03/index.html >, (参照日 2017 年 9 月 30 日).

環境省, 2050 年再生可能エネルギー等分散型エネルギー普及可能性検証検討委託業務報告書 (2015), available from <https://www.env.go.jp/earth/report/h27-01/index.html >, (参照日 2018 年 1 月 12 日).

Sakamoto, T., Takase, K., Matsuhashi, R. and Managi, S., Baseline of the projection under a structural change in energy demand, Energy Policy, Vol.98 (2016), pp. 274-289.

佐藤治, 我が国の長期エネルギーシステム需給シナリオに関する検討, JAERI-Research 2005-12 (2005).

高橋尚也, 田部豊, 近久武美, 鈴木研悟, 北海道における風力・太陽光発電の大量導入に向けた変動対策の効果と 長期導入シナリオ解析, 第 33 回エネルギー・資源学会エネルギーシステム・経済・環境コンファレンス講演 論文集, CD-ROM (2017), pp.479-484.

柳雄祐, 田部豊, 近久武美, 北海道の中長期的な $\mathrm{CO}_{2}$ 排出削減目標量に対寸るエネルギー構成変化ならびにコス 卜解析, 第 20 回動力エネルギーシンポジウム講演論文集(2015), pp.335-336.

\section{References}

Akimoto, K. and Sano, T., Analyses on japan's GHG emission reduction target for 2050 in light of the $2^{\circ} \mathrm{C}$ target stipulated in the paris agreement, e-Journal of Japan Society of Energy and Resources, Vol.38, No.1 (2017) (in Japanese).

International Energy Agency, World energy outlook 2010 (2010), available from <http://www.env.go.jp/earth/report/h23-03/index.html >, (accessed on 30 September, 2017).

Komiyama, R. and Fujii, Y., Optimal integration of variable renewables in electric power systems of japan, Journal of Energy Engineering, Vol.143, Issue 3 (2017).

Loulon, R., Goldstein, G. and Noble, K., Documentation for the MARKAL family of model (2004).

Ministry of the Environment, Study of potential for the introduction of renewable energy (2011), available from <http://www.env.go.jp/earth/report/h23-03/index.html >, (accessed on 30 September 2017) (in Japanese).

Ministry of the Environment, 2050nen saisei kano enerugi to bunsangata enerugi fukyu kanosei kensho kento itaku gyomu 
hokokusho (2015), available from <https://www.env.go.jp/earth/report/h27-01/index.html >, (accessed on 12 January 2018) (in Japanese).

Sakamoto, T., Takase, K., Matsuhashi, R. and Managi, S., Baseline of the projection under a structural change in energy demand, Energy Policy, Vol.98 (2016), pp. 274-289.

Sato, O., A Study of Long-term Energy Scenarios for Japan, JAERI-research 2005-12 (2005) (in Japanese).

Takahashi, N., Tabe, Y., Chikahisa, T. and Suzuki, K., Effect of counter measures and analysis of long-term installation scenario for large-scale penetration of wind and solar power in Hokkaido, 33th Conference on Energy, Economy, and Environment (2017), pp.479-484 (in Japanese).

Yanagi, Y., Tabe, Y. and Chikahisa, T., Analysis of changing energy structures and total costs for medium to long-term $\mathrm{CO}_{2}$ reduction targets in Hokkaido, 22nd National Symposium on Power and Energy Systems (2015), pp.335-336 (in Japanese). 